\title{
Neoliberal Küreselleşme, Değişen Sosyal Politikalar ve Yoksulluk Sorunsalı Üzerine Bir Tartışma
}

DOI: $10.26466 /$ opus. 934568

\author{
* \\ Orhan Orhun ${ }^{*}$ - Osman Şimşek ** \\ * Dr. Arş. Gör., Batman Üniversitesi, Batman/Türkiye \\ E-Posta: orhanorhun06@hotmail.com \\ ORCID: $\underline{0000-0002-3735-2865}$ \\ ** Dr. Öğr., Adnan Menderes Üniversitesi, Aydın/Türkiye \\ E-Posta: osmnsmsek7@gmail.com \\ ORCID: 0000-0001-5619-704X
}

\section{Öz}

Çalı̧mada neoliberal küreselleşmenin izdüşümünde yoksulluk sorunsalının ve sosyal politikalarm tarihsel süreç içerisindeki dönüşümü ve görünümleri analiz edilmektedir. Bu bağlamda tartışma, öncelikle yoksulluk sorunsalının derinleştiği sanayi devrimini ve bu dönemdeki tartışmalı refah devleti anlayışın ele almaktadır. Ardından tarih sahnesine egemen olan neoliberal küreselleşme kıskacında; yeni yoksulluk ve sosyal politikalar tartışmanın odağını oluşturmaktadır. Yoksulluk ve sosyal politika olgusunun tarihsel arka planı oldukça uzun bir geçmişe sahip olsa da, çalışmada bu olgu görünürlü̆̆̈̈nün belirginleştiği sanayi devrimi ve sonraki dönemler üzerinden analiz edilmektedir. Sanayi devrimi ile yoksulluk sorunsalı ve sosyal politikalar tarihin hiçbir döneminde olmadığı kadar belirgin hale gelmiştir. Sanayi devrimi sonrasında küreselleşme ve yükselen neoliberal politikalarla; yoksulluk ve sosyal politika algısında da değişimler olmuştur. Son olarak neoliberal küreselleşme ile piyasa toplumunun yükselişi sosyal politika ve yoksullar üzerinden yeni tartışmaları doğurmuştur. Bu bağlamda sanayi devriminin piyasa ekonomisi risklerine karşı geliştirilen keynesyen refah devleti politikaları ve eleştirileri alt temalar üzerinden tartışılacaktır. Çalışma, yoksulluk sorunsalını bu temel dinamikler çerçevesinde çok yönlü tartışmayı amaçlamaktadır.

Anahtar Kelimeler: Küreselleşme, Neoliberalizm, Sosyal Politika, Yoksulluk. 


\title{
A Discussion on Neoliberal Globalization, Changing Social Policies and the Problem of Poverty
}

\begin{abstract}
In this study, the transformation and appearance of the poverty problem and social policies through the historical process in the projection of neoliberal globalization have been analyzed. In this context, the discussion has primarily dealt with the industrial revolution, in which the poverty problem deepened, and the controversial intellection of the welfare state in this period. Then, in the grip of neoliberal globalization that dominates the stage of history; new poverty and social policies have constituted the focus of the discussion. Although the historical background of the phenomenon of poverty and social policy has a long history, the study has been analysed on the basis of the industrial revolution and subsequent periods, where its visibility has become clear. With the industrial revolution, the poverty problem and social policies have become more evident than in any other period of the history. Changes in poverty and social policy perception have also been with globalization and rising neoliberal policies after the industrial revolution. Finally, the rise of the consumer society with neoliberal globalization has led to new discussions over the social policy and the poor. In this context, Keynesian welfare state policies and criticisms developed against the market economy risks of the industrial revolution will be discussed through subthemes. This study aims to discuss the poverty problem from multiple perspectives within the framework of these basic dynamics.
\end{abstract}

Keywords: Globalization, Neoliberalism, Poverty, Social Policy, Poverty. 


\section{Giriş}

Yoksulluk sorunsalı, günümüz postmodern dünyasının en önemli sorunlar1nın başında yer almaktadır. Oldukça geniş bir tarihsel sürece sahip olan yoksulluk sorunsalı, insanlık tarihinde köklü değişiklere sebep olan Sanayi Devrimi ile zirve noktalarından birine ulaşmıştır. Sanayi Devrimindeki kapitalist üretim ilişkileri ile toplumda sermaye (burjuva) ve emek (işçi) akslı iki uç sınıf tarih sahnesinde merkezi öneme sahip bir yer edinmiştir (Aydoğanoğlu, 2010). Kapitalist paradigma eksenli ilerleyen Sanayi Devriminde, toplumda azınlıklık olan burjuva sınıfı günden güne zenginleşirken, toplumun büyük çoğunluğunu oluşturan işçiler ise yoksullaşmaya doğru sürüklenmişlerdir. Bu kutuplaşma ile bir yandan yoksulluk kitleselleşirken öte yandan zenginlik bir avuç azınlığın elinde yoğunlaşmıştır. Endüstri teknolojisinde meydana gelen değişimler; kırsalda yaşayan nüfusun büyük bölümünü kentlere işçi olarak göç etmeye zorlamıştır. Doğal yaşam alanlarından kopup gelen ve mülksüzleştirilen emek gücü, kentlerdeki fabrikalarda emeklerini ücret karşlığında fabrika sahiplerine yok pahasına satmak zorunda kalmıştır (Marx, 2011, s.620-621). Fabrika sahipleri ile işçiler arasındaki bu ilişki temelde; emeğin ağır sömürüsüne dayanmaktadır. İşçiler emeklerinin karşılığını alamamış yahut düşük ücretler ve kötü koşullar altında çalışmak zorunda bırakılmıştır. Bu dönemin önemli gelişmelerinden biri ise makinelerin üretim sürecine hızla dahil olmasıdır. Böylelikle kas gücü yerini her geçen gün makinelere bırakmış, dolayısıyla insan emeğine duyulan ihtiyaç her geçen gün azalmıştır. Bu durumda; emekleriyle geçimlerini sağlamakta zorluk çekenlerin, kentlerin çeperlerine yedeklenmiş işsizler ordusunun, tarım emekçilerinin, kırsaldan gelen mülksüz köylülerin, kısaca ürettiklerinden daha azını almak zorunda kalan ve emeklerini kullanmalarına olanak tanınmayan, emekçi dahi olmaları mümkün olmayan dışlanmış kitlelerin (Köse ve Bahçe, 2009, s.392) yoksullukta ortaklaşmalarına neden olmuştur.

Bu çerçeveden hareketle, bu çalışmada literatür taraması tekniği kullanılarak eleştirel bir perspektif ile Sanayi Devrimi dönemindeki köklü değişimler ve bu değişimlerin günümüz küresel yapısındaki yansımaları incelenmektedir. Bu köklü değişimler çerçevesinde işsizlik ve yoksulluğun günden güne nasıl derinleştiğini tartışmaya açan bu çalışma, ekonomik ve toplumsal yaşam üzerinden refah devletinin ortaya çıkışını ve beraberinde getirdiği sos- 
yal politikaları sorgulamaktadır. Daha sonrasında refah devleti ve sosyal politikalarıyla ilişkili olan keynesyen politikaların nasıl uygulandığının sorgusunun ve eleştirisinin yapıldığı bu çalışmada, neoliberal küreselleşme olarak kavramsallaştırılan günümüz ekonomik ve toplumsal yapısında yoksulluk sorunsalı incelenmektedir.

\section{Sanayi Devrimi Yoksulları}

Sanayi devrimi ile beraber; hızla artan iş bölümü, teknolojideki gelişmeler ve bu gelişmeler sonucu artan makineleşme ve emeğin fabrika disiplini ile kontrolü, eşitsiz bir gelişimi ortaya koymuş ve bu gelişim yasası ile birlikte bir yandan zenginlerin serveti artmış diğer yandan ise sefalet endişe verici boyutlara ulaşmıştır. Bu dönemde metalaştırılan emeğin sömürüsünün, sosyal sorunların (yoksulluk, işsizlik, hastalık, vs.) ve sosyal gerilimlerin giderek arttığı görülmektedir (Güven, 1995). Dolayısıyla gittikçe artan işsizlik ve bunun doğal sonucu olarak artan yoksulluk, kapitalist sistemde belirli soruları gündeme taşımıştır. Sanayi kentlerine doğru yaşanan yoğun emek göçüyle artan yoksulluktan kurtulmanın formülü olarak sunulan çalışma etiği ve yoksulluk yasaları da artık iş göremez hale gelmiştir. Burjuva sınıfının yoğun sömürüsü ve artan istihdam sorunlariyla birlikte iş gücü giderek kitlesel yoksulluğa itilmiştir. Topraklarından koparılıp sanayi kentlerine göç eden nüfus, kapitalist üretim ilişkileri içerisinde ezilmiş ve bu dönemde insan sadece üretime dahil oldukça var olabilmiştir. Bauman'ın (2003) da belirttiği gibi, bu dönemde; olası herhangi bir durumdan dolayı değişime ayak uyduramayanlar, iki yakasını bir araya getirmesi mümkün olmayanlar, ortaya çıkan koşullar altında varlığını bile sürdüremeyenler ve hayatlarını sürdürmek için gelir sağlama gerekliliği bulunan insanlar için bir alternatif bulunmamaktadır. Bauman'a göre her birey fabrikanın çarkları altına sürüklenemezdi; fabrikadaki zor çalışma şartlarının üstesinden gelebileceğini kimsenin düşünemeyeceği güçsüzler, sakatlar, hastalar ve yaşlılar gibi çeşitli dezavantajlı gruplar bulunmaktaydı. Bu gruplar her kesim için bir tehdit oluşturmakta ve beraberinde kapitalist topluma dair ciddi sorgulamaları getirmekteydi (Ilkin, 1973).

Bu sorgulamalar düşünülenin aksine, öncelikle yoksulların lehine olmamıştır. Başlangıçta yoksulluk bireyin bir tercihi olarak görülmüş veya yoksullardan kurtulmanın kesin ve ucuz yolları aranmıştır. Bu durumu en iyi Carlyle'nin (1996) ve Himmelfarb'ın (1984) o dönemde yoksulluk üzerine 
yazdıkları metinlerde görmekteyiz. Carlyle (1996) şöyle aktarır: “Eğer yoksullar sefil bir duruma düşürülürse büyük ölçüde azalacaklardır. Tüm fare avcıları şu sırı bilir; tahıl ambarının deliklerini tıkayın, devamlı miyavlamalar, panik ve patlayan tuzaklarla başlarına bela olun, suçlanabilir emekçileriniz ortadan kaybolacaklar ve binayı terk edeceklerdir. Aksi takdirde caiz olan, daha kısa, belki de daha az sorun çıkaran metot arseniktir." Himmelfarb (1984) ise şöyle açıklamaktadır: "Yoksullar, fareler gibi, bu metotla gerçekten ortadan kaldırılabiliyor ya da en azından görüş menzilinin dışına itilebiliyordu. Gereken tek şey, yoksullar ve talihsizlerin sadece yok edilmesi gereken bir bela olduğunu farz ederek onlara fareler gibi davranma kararlılığıdı."

Bauman'a (1999, s.23) göre yoksullardan o dönemde basitçe kurtulmaya dair bir yöntem mevcut değildi ve bunun yokluğunda, daha az mükemmel olan bir başka çözüm bulunması gerekmekteydi. Bu nedenle sosyal politikalarda reformlar yapılmaya başlandı. Sosyal politikalar günümüzde olduğu gibi o dönemde de sermaye lehine araçsallaştırılmıştır. Böylelikle sosyal politikalar sayesinde, işsiz ordusu sürekli dinç tutulmaya çalışılarak, gerektiğinde kullanıma hazır hale getirilmiştir. Ayrıca sosyal reformlar başlangıçta çalışma etiğine hizmet edecek şekilde tasarlanarak, yoksullara kötü koşullar altında çalı̧̧maktan başka seçenek bırakmayacak şekilde hazırlanmıştır. Bauman'a (1999, s.28) göre düşkünlerevi dışında yardım yok kuralı, 'seçeneksiz' durumu oluşturma hamlesinin bir belirtisidir. Aynı stratejinin bir diğer belirtisi kıt kanaat yaşamın özendirilmesidir, yani ücretleri çalışılacak ertesi günün şafağına kadar hayatta kalabilecek derecede düşük tutmak ve böylece bu yoğun çalışma gününü bir zorunluluk, bir 'seçeneksizlik' durumuna sokmaktır. Sanayi devrimindeki üretim ilişkilerinin yarattığı bu kriz refah devletinin ortaya çıkışına kadar tüm yoğunluğuyla devam etmiş ve refah devletinin ürettiği sosyal politikalar ile bu seçeneksizlik durumuna çözüm aranmaya çalışılmıştır.

\section{Refah Devletinin Yükselişi ve Sosyal Politikalar}

Tarih boyunca bütün insan gruplarında bakımını sürdürmekte zorluk çeken; engelliler, yoksullar, yetimler, işsizler, akli dengesi bozuk olanlar gibi insanlar bulunmaktadır. Haliyle her dönemde bu grupların ihtiyaçlarının karşılanması amacıyla çeşitli politika ve stratejiler geliştirilmiştir (Zastrow, 2015:18). 
Başka bir ifadeyle, sosyal politikalar medeniyetin başlangıcından beri var olagelmiştir. Sosyal politikalar bu boyutuyla bize geniş tanımını sunarken, özelde sanayi devrimiyle birlikte sosyal politikaların işçi sınıfı merkezli olduğunu sunmaktadır (Koray, 2008, s.4).

Sanayi devrimi sonrası artan kitlesel yoksulluk karşısında refah devletinin yükselişine tanık olmaktayız. Bauman (1999, s.67) refah devletini, "tüm uyruklarının refahını (yani sadece hayatta kalmaktan fazlasını; belirli bir toplumda, belirli bir zamanda, onurlu bir şekilde hayatta kalmayı) sağlamanın devletin yükümlülügü olduğu" şeklinde ifade etmektedir. Şenkal'e (2005) göre ise refah devleti, kapitalist üretim ilişkilerine sahip toplumlarda sanayileşmenin doğurduğu sorunlar, güvensizlik ve eşitsizlik karşısında siyasal hakların gelişmesi ile beraber, devletin bu süreç karşısında tepki göstermesi ve engellemesi gerektiği düşüncesi ile gelişmektedir. Şenkal (2005) refah devletini, ailelere ve bireylere asgari geçim güvencesi veren, olası toplumsal tehlikeler karşısında onları koruyan, sosyal güvenlik imkanı tanıyan, barınma, sağlık, eğitim gibi sosyal hizmet alanlarına belirli standartlar getiren devlet olarak tanımlamaktadır.

Geniş tanımı ile refah devleti, kapitalist ekonominin ve bu temelde oluşan siyasal yapının dinamiklerini koruyarak, kapitalist ekonominin sebep olduğu eşitsizlikleri ortadan kaldırmak ve kapitalist ekonominin sunduğu imkanların toplumun tüm bireyleri tarafindan yararlanılması ile hümanist bir temelde yaşam sağlama görevini üstlenen devlet olarak tanımlanmaktadır. Sosyal devlet anlayışı, sosyal adaletin ve sosyal barışın sağlanmasını amaç edinen, sosyo-ekonomik hayata müdahaleyi normalleştiren ve gerekli kılan devlet anlayışıdır (Özbudun, 1995). Ayrıca sosyal devlet anlayışı, vatandaşlarına asgari bir yaşam sunarak onların sosyal durumlarını ve refahlarını üstlenen devlet anlayışı olarak da tanımlanmaktadır (Yılmaz, 2005). Günümüzde de sıklıkla gündeme gelen asgari bir yaşam düzeyinin sınırlarını, hala egemen/burjuva çizmektedir. Bu açıdan sosyal politikalar sanayi devriminde olduğu gibi günümüzde de kitleleri asgari bir yaşamın sinırları içinde tahayyül ederek, baskı ve kontrol mekanizması oluşturmaktadır.

Sallan Gül'e (2004, s.144) göre kabaca sosyal refah devleti, sanayileşmiş ülkelerde ortaya çıkmış olan bir form olarak tanımlanmaktadır. Bu ülkelerde sosyal refah devletinin ortaya çıkmasının sebebi ise, kapitalizmin yaşadığ krizler ve bu krizler ile ortaya çıan zorunlu değişimlerdir. Sanayi devrimiyle 
birlikte kapitalist sistemde yoksulluğu arttıran iki temel kriz meydana gelmiştir. Bunlardan ilki, makine teknolojisinin gelişimi ile emeğe duyulan ihtiyacın azalması ve üretim fazlalığının ortaya çıkışıdır. Diğeri ise kapitalist ideolojinin tüketim toplumu üzerinden kendini devam ettirmesi ile ortaya çıkan yoksulluk ve sosyal politika bazlı sorunlardır.

Bauman'a (1999, s.68) göre refah devletinin temel işlevleri şöyle sıralanabilir: Refah devleti öncelikle, kriz ve buhran dönemlerinden olumsuz etkilenen, dolayısıyla işsiz kalanların 'normal davranma'sını sağlamaktadır. Sonrasında ise işler yoluna girdiğinde, sanayinin ihtiyaç duyduğu 'yedek işsiz ordusu'nu her daim kullanım ve hizmete uygun şekilde çalışmaya hazır tutmaktadır. Böylece refah devleti bireylerin hizmet sunamadığı anlarda doğru biçimde muhafaza edilmesini sağlamaktadır. Refah devleti, çalışma etiğiyle; çalışma ve sosyal yaşamı canlı tutarak, üretimin önünde oluşabilecek aksi durumları azamiye indirmeye katkı sunmaktadır. Refah devletinin bir diğer önemli işlevi ise, "emeğin yeniden metalaştırılması" için sağladığı alt yapıdır. Fabrikalarda hizmete her an hazır emek gücünden oluşan düzenli bir stok oluşturulması için; onlara eğitim, sağlık, konut sağlanmış ve fakir ailelerin çocukları için sağlıklı beslenme olanağı yaratılmıştır. Bu sayede refah devleti tek başına şirketlerin yahut firmaların ulaşamayacağı topyekûn bir verim elde etmiştir. Bunların yanı sıra, refah devleti bir hak olarak; sanayi döneminde göstermiş olduğu başarı ile barış getirici ve barışı koruyucu işleviyle de algılanmıştır. Bauman (1999, s.68-69), tüm bu sonuçların uzun vadede burjuvanın lehine işlediğini ifade ederek; refah devletinin, işçilerinin burjuvanın belirlediği yasalara itaatini daha iyi sağladığını ve bunu salt baskıcı ve zorba tedbirlerle desteklenen ve yüksek enerji harcanan çalışma etiğinin yapabileceğinden çok daha ucuza ve az enerji kullanarak başardığını vurgulamaktadir.

Özdemir (2007, s.177) refah devletinin gelişim ve değişimini genel olarak şu sınıflandırmalar üzerinden incelemektedir: Sanayi devrimi öncesi olarak da kabul edilen 1980 öncesi dönemde var olan sorunların çözümü için gönüllü kuruluşların, aile kurumunun, hayırseverlik şiarıyla harekete geçen kurumların ve genel olarak bu sorunun çözümü için gerekli sorumluluğu hisseden işverenlerin ve devlet gelir yatırımlarının var olduğu görülmektedir. Daha sonrasında, 1880-1945 yılları arasında, işçiler kendilerinin zorunlu finansmanlarını sağladıkları sosyal sigorta kurumlarının güvencesi altına alınmışlardır. 1945-1975 yıllarını kapsayan dönemde ise, refah devletinin altın 
çağı olarak belirtildiği refah dönemi başlamıştır. Bu yıllar arasında refah devletinin işlevini ve kurumlarını genişletmek, sosyal sigortaların yanı sıra gelirin sürekliliğini sağlamak ve daha iyi bir hayat için yaşam kalitelerini yükseltmek amaç haline gelmiştir. 1975 sonrası dördüncü dönem ise, kriz dönemi olarak adlandırılmakta ve yeniden yapılandırma arayışlarının başladığı süreci ifade etmektedir. Bu dönem ayn zamanda neoliberal küreselleşmenin yükseldiği döneme denk gelmektedir.

Özdemir (2007, s.21) refah devletinin tarihsel süreç içerisindeki dönüşümünü verdikten sonra genel olarak üç temel özelliği ortaya koymaktadır. Birinci özelliği refah devletinin müdahaleci oluşudur; refah devleti başarısız olan piyasa politikaları üzerine eyleme geçer ve bu kriz sonucu ortaya çıkan problemlerin çözümüne yönelik önlemler alır. İkinci özelliği düzenleyici oluşudur; refah devleti, piyasa mantığının yoğun emek sömürüsünü engellemek ve işçilerin yoksulluk durumuna düşmemesi için asgari ücret belirler, yardım ve güvenliğe dair sosyal politikalarına sahip çıkar. Son olarak, gelirin yeniden dağıtıcısı konumunda oluşudur; sınıflar arasında yüksek eşitsizliklerin ve dengesizliğin önlenmesi için gelir dağılımına müdahale edebilmektedir. K1sacası refah devleti yaptı̆̆ çeşitli düzenlemelerle, ekonomik ve sosyal krizler karşısında bireyleri korumayı amaçlamaktadır. Sosyal politikalar aracılığı ile bu koruma gerçekleşmektedir. Ayrıca, refah devletinin müdahaleci, düzenleyici ve dağıtıcı özelliklerinin var olmasının temel sebebi, serbest piyasa ekonomisinin karşısında çözüm üretebilmektir. Bu noktada çözüm ise Keynesyen politikaların sahneye çıkışıyla gerçekleşmektedir.

\section{Piyasa Toplumuna Karşı: Keynesyen Politikaların Zorunluluğu}

Sanayi devriminin yarattığı kapitalist serbest piyasa ekonomisinin oluşturduğu risklerine karşı devletler, Keynesyen politikaları benimseyeme başlamıştır. O dönemde etkin olan serbest piyasa ekonomisinin doğurduğu vahim sonuçlar nedeniyle, müdahaleci devlet anlayışı da giderek baskın hale gelmiştir (Özdemir, 2007). Refah devletinin temel özelliği olan müdahaleci ve düzenleyici yönü burada ortaya çıkmaktadır. Serbest piyasa ekonomisinin doğurduğu risklere karşı devlet, ekonomik ve sosyal risklere karşı çalışanları, çalışmayanları ya da engelli olanları da sosyal sigorta sistemi ve sosyal güvenlik ile güvence altına alarak, asgari bir yaşam derecesi sağlamayı görev edinmiştir. Keynes tarafından 1930 ve 40'lı yıllarda bu bakış açısı özellikle 
vurgulanmıştır (Sallan Gül, 2004, s.147). Refah devleti en temelde kapitalist üretim ilişkilerinin oluşturduğu olası risklere karşı bir güvence sunma girişimidir. Refah devletinin piyasadan çekilmesini zorlaştıran en önemli unsur da bu piyasa toplumu riskine karşı geliştirdiği fren sistemi olmaktadır.

Refah devleti ve yoksulluk üzerine gerçekleştirilen tartışmaların uğrak noktası, Keynesyen politikalarla yakından ilişkilidir. Klasik liberal politikalar, ekonomiyi düzeltmek için daha fazla işçiyi yoksulluğa sürüklerken, Keynes'e göre, kitlesel boyutlara ulaşan işsizlik bir arz problemi değil, bilakis bir talep sorunudur. Dolayısıyla işsizler için maksimum işsizlik ödenekleri ve devletlerin istihdam sağlamak amacıyla oluşturacakları yatırımlar problemlere köklü çözümler sunabilir (Özdemir, 2007, s.194). Keynes, serbest piyasanın dengesiz haline dikkat çekerek, özellikle istihdam konusunda istikrarın sağlanması için devlet müdahalesi yoluyla önlemlerin alınması gerekliliğini vurgular. Keynesyen politikaları benimseyen refah devletinin, amacına varabilmesi için toplam talebi yönlendirebilecek, istihdamı tam sağlayacak, ekonomik büyüme ve istikrarı koruyacak çeşitli önlemler alınmalıdır (Sallan Gül, 2004, s.147). Keynes bu politikaların kısa vadeli olması gerektiğini ve devletin katkısını iyileşmeler sonrası terk etmesi gerektiğini belirtse de, pratikte bu durumun hiç de kolay olmadığı görülmektedir. Keynesyen politikaları benimseyen devletler ekonomide önemli ve güçlü bir aygit haline gelmiştir ve bu durum haliyle devletlerin geri çekilmelerini de zorlaştırmıştır. Refah devletinin artan gücü bir süre sonra sermayenin devlette toplanmasına sebep olmuş ve böylelikle yeni güç ve iktidar ilişkileri ortaya çıkmıştır.

Keynesyen politikaları benimseyen refah devletleri, talep yönetimine uygun planlanan ekonomilerde ilk olarak ciddi bir büyüme sağlamış, istihdamı arttırmış, ücretleri ve iş hayatı koşullarını iyileştirerek önemli bir ivme kazanmıştır. Refah devletleri, hızlı ekonomik büyüme sayesinde maddi kaynaklarını arttırmış ve bu kaynakların görece doğru kullanımıyla özellikle II. Dünya savaşı sonrası altın çağını yaşamıştır. Bu süreçte kapitalist devletin, eşitsizlikçi görünümlerini belli ölçülerde de olsa gidermiştir. Diğer yandan refah devletlerinde bu kaynakların dağıtımı ile ilgili adalet üzerinden önemli sorgulamalar yükselmiştir. Refah devleti, kaynakların dağıtımı noktasında siyasi ve ekonomik ilişkilerin de devreye girmesiyle adil olamamaktadır (Acar, 2007). Kaynakların bu eşitsiz dağılımı beraberinde yeni yoksulları doğurmakta ve yoksullar arasında birleşmeyi kırmaktadır. Ayrıca refah devletinin 
toplumdaki eşitsizliği görece gidermesi çoğunlukla yoksulluğun örtükleşmesine neden olmaktadır. Son olarak, unutulmamalıdır ki refah devleti ile yoksulluk arasındaki ilişkinin çift yönlü oluşu; sürekli birbirlerini yeniden üretmelerine de neden olmaktadır.

\section{Refah Devleti Politikalarına Yönelik Eleştiriler}

Refah devleti ve sosyal politikalar üzerine her dönem çeşitli tartışmalar ve eleştiriler sürdürülmektedir. Eleştirilerin temel noktası; alınan önlemlerin beklenen sonuçları gerçekleştiremediğine ilişkin olmaktadır. Eleştiriler, sosyal harcamalara ayrılan onca bütçeye rağmen işsizlik, yoksulluk, güvencesizlik, kuralsızlık gibi çeşitli problemlerin çözülemediği, eşitliğin bir türlü sağlanamadığı, devletlerin yurttaşların hayatlarına pek çok açıdan karıştığı, ağır aksak işleyen bir kamusal bürokrasiye neden olunduğu, sosyal politikalara yapılan harcamalarının yüksek maliyetinin taşınamaz düzeylere ulaştı̆̆ 1 ve harcamalarda etkinliğin sağlanamadığı noktalarında yoğunlaşmaktadır (Harvey, 2007, s.2). Bu eleştiriler bağlamında, sosyal refah politikaları beklenen iyileştirici etkisini gösterememiş ve ekonomik anlamda başarısız olarak görülmüştür (Clasen, 2003, s.573). Ayrıca refah devletinin üstlendiği yeniden dağıtımcı rolü, bu imkanlardan daha fazla yararlanmak isteyenleri devlet kurumlarına yakınlaştırmış, bürokratlara türlü iş birlikleri sunarak pazarlığa girişilen adil olmayan alanların oluşmasına sebep olmuştur (Acar, 2007: 45).

Bu politikaların günümüzde de devam ediyor oluşu, sosyal politikalara dair eleştirilerin günümüze değin sürmesine neden olmuştur. Refah devleti, günümüzde özellikle popülist sağ politikalar tarafından; devletler tarafından sıklıkla ekonomiye yapılan müdahaleler neticede piyasalarda haksız rekabet yaşandığı, doğası gereği devlet kurumlarının verimsiz ve pahalı çalıştığı, devletin müdahalesi sonucu piyasalarda tekeller yaratıldığı, tüketiciye çoğu kez niteliksiz yahut sınırlı sayıda ürün sağlandığı ve tüketicinin ürüne mecbur kalmasına neden olunduğu, ekonomik alanda devletin etkin bir güç haline geldiği ve böylece gücün egemende yahut ona yakın olanlarda toplanmasına neden olduğu, dolayısıyla bireylerin gücün dışına itildiği, sosyal adalet sağlama endişesiyle gerçekleştirilen çeşitli politikalarla çeşitli hizmetleri düşük maliyet veya ücretsiz sunduğu ve böylece emeksiz hizmet almayı özendirdiği, bu alanda gerçekleştirilen sosyal harcamaların haksız gelir dağılımına sebebiyet verdiği yönünde eleştirilmektedir (Sezen, 1999, s.55-56). 
Yukarıda sunulan eleştiriler çoğunlukla neoliberal kapitalist küreselleşme ideolojisini pekiştirmektedir. Başkaya (2000, s.108-109) bu durumu "çok uluslu şirketler küresel anlamda ekonominin gelişimini tekellerine almıştır" şeklinde ifade etmiştir. Söz konusu şirketler, devletlerin koyduğu her türlü sinırlamalara ve denetimlere meydan okumaktadırlar. Artık gelişmenin dinamosu olarak bu şirketler görülmektedir. Çok uluslu şirketlerin bu iddiaları, sermayenin dolaşımını engelleyen politikaların kalkmasıyla, ülkeler arasındaki eşitsizliklerin giderileceği yani homojenleşme yaşanacağı ve böylelikle refahın da küreselleşeceği yönündedir. Bu iddialar ile beraber küreselleşme süreci, toplumsal yapıda kısa bir süre içinde önemli ve köklü değişimler ortaya çlkarmıştır. Başlangıçtaki refahın küreselleşeceği vaatlerinin aksine; dünyada temel ekonomik göstergeler ve gelir dağılımı dengeleri arasında önemli farklılıklar ortaya çıkmıştır. Zenginler her geçen gün sermayelerini katlarken yoksullar giderek daha da güç durumda yaşamaya zorlanmıştır. Yaşanan bu toplumsal dönüşümlerden öncelikli olarak etkilenen yapılardan biri de sosyal politikalar alanıdır.

Doğası gereği rekabeti her an gerekli kılan neoliberal küreselleşme nedeniyle sürekli rekabet içerisinde olan ülkelerde, sosyal politikalar alanında yapılan harcamaların önemli boyutlara ulaşması sebebiyle sosyal politikalar, ülkeler tarafından, yarış içerisinde başarılı olmak için atılması gereken yük olarak algılanmaktadır. Oluşturulan bu yük algısının küreselleşme sürecinde sürekli yarış halinde olan tüm devletler tarafından benimsenmesi, küresel boyutta sosyal devletten uzaklaşılmasına neden olmaktadır (Ertuğrul, 2004). Bu süreç neticesinde; sosyal harcamalarda ortaya çıkan kısıtlamaların yanında, devletlerin piyasa üstündeki etkisinin indirgenmesini sağlayacak özelleştirmelerin yaygınlaşması ve şefkatli sosyal refah devleti düsturundan öte uluslararası düzeyde rekabete karşı direnç geliştirebilen ve devletin varlığın sürdürmesine olanak sağlayacak şirketlerin yararları egemen olmaya başlamaktadir.

Sallan Gül (2004, s.172) sosyal politikaların gizli işlevine de dikkat çekerek; devletin korumacı politikalarının yoksulluğu kısmi bir şekilde önleyerek, olası protest hareketlerin önünü kestiğini ve kontrol ettiğini belirtir. Marksist bakış açısı da benzer şekilde; refah devletinin kitleler üzerindeki hegemonik gücüne dikkat çekerek, kapitalistler ya da egemen sınıfın sosyal politikalar aracılığıyla, işçilerin ekonomi, özgürlük, eşitlik, hak ve toplumsal adalet ta- 
leplerini karşılar bir görünüm sergileyerek; protesto ve oluşabilecek devrimlerin engellenmeye çalışıldığını savunmaktadır (Köse ve Bahçe, 2009). Marcuse da (1968: 88) bu duruma dikkat çekerek, sosyal politikalar aracilığıyla işçi sınıfının denetim altında tutulmaya çalışıldığını, böylelikle kapitalist üretim ve birikim sürecinin devamının sağlandığın ifade etmektedir. Marksist perspektiften yöneltilen bu eleştirilerin temel noktasi; kapitalist düzenin sürdürülmesi ve bu sürekliliğin garanti altına alınması için refah devletinin, sermaye lehine kullanılmasıdır. Sonuç olarak sosyal politikaların araçsallaştırılmasıyla, özellikle de sosyal yardımlarla, neoliberalizmin fayda sağladığı tüketimin dişında kalan yoksul kesimlerin piyasaya yeniden entegre edilmesine olanak tanınmaktadır.

Refah devletinin gelişim sürecinde iki temel işlevi karşımıza çıkmaktadır. İlki, sosyal politikaların her geçen gün genişleyen anlamıla serbest piyasa ekonomisine karşı bireyleri belirli oranda korumakta olduğudur. İkinci ise, kapitalist paradigmanın sosyal politikaları araçsallaştırılarak yaşadığı krizleri aşmak için onları kullanmakta olduğudur. Refah devletinin bu işlevlerinin yanı sıra onun önemli bir güç haline gelmesi, bu alana ilişkin güç ve iktidar sorgulamalarını da beraberinde getirmiştir. Ayrıca bu durum, kapitalist sisteme ilişkin çatışmaları, muhtemel işçi isyanlarını, başkaldırıları ve sosyalizm tehdidini kırma amacını da içermeye başlamıştır (Durdu, 2009, s.13). Refah devletinin, burjuvazi ile isçi sınıfı arasındaki toplumsal uzlaşmayı sağlayacak bir mekanizma yaratma girişimi, isçi sınıfının yeniden dağıtımında etkin olarak rol oynayan sosyal devletin ve toplumsal müzakere sisteminin varlığına karşılık gelmektedir. Bu durum ayrıca özel mülkiyeti temel alan üretim ilişkilerine itiraz etmemeyi kabul ettiğini göstermektedir (Rosanvallon, 2004, s.17).

Sonuç olarak; başlangıçta klasik liberalizmin yarattığı sorunlara bir alternatif olan sosyal refah devleti, sanayi devrimi ile ortaya çıkan sosyal sorunların sistem içinde kalınarak çözülebileceğini savunmuştur. Sistemin aksayan, sosyal bütünleşmeyi engelleyen, sosyal dengeyi ve uyumu bozan yönlerinin sosyal reformlar yapılarak düzeltilebileceği ileri sürülmüştür. Bu reformist anlayış beraberinde yoksullukla ilgili yeni sorgulamalar doğurmuştur. Yoksullara sunulacak destekler ile "yoksulun belirlenmesi" sorusu gündeme gelmiştir. Ne yazık ki bu soruya her defasında insan onuruna oldukça uzak bir noktadan cevap verilmiştir. Yoksulun belirlenmesinde kullanılan insanlık 
dışı şartların yanı sıra, bu algı yoksul bireylere yönelik dışlamaları ve damgalamaları da beraberinde getirmiştir.

\section{Neoliberal Küreselleşme Kıskacında Sosyal Politikalar ve Yoksulluk}

Sosyal politikaların dar ve geniş anlamlarına ek olarak, neoliberal küreselleşme ile sosyal politikaların üçüncü bir anlamının da var olduğu görülmektedir. Günümüzde artık sosyal politikaların anlamı "ulus ötesi" bir boyuta ulaşmıştır. Sosyal politikanın ulus ötesi anlamı, neoliberal küreselleşme olgusu ile yakından ilintilidir. Neoliberal küreselleşmesinin etkisiyle, devletlerin temel işlevleri; ulusal kalkınma, sosyal ve ekonomik gelişmeye dayalı sosyal refah anlayışına paralel olmaktan öte uluslararası serbest piyasa ekonomisine uyum sağlayacak şekilde ilerlemektedir. Küreselleşme süreciyle yaşanan toplumsal ve ekonomik değişimler aynı zamanda sosyal refah anlayışını ve yoksulluk olgusunu da dönüştürmektedir. Bu durum, sosyal politika ve yoksulluk olgusunun küresel boyutta ele alınmasını gerekli kılmaktadır. Dolayısıyla öncelikli olarak bu kısımda küreselleşmeye dair tanımlar sunulacaktır. Ardından neoliberal küreselleşme sürecinin temel dinamikleri ışı̆̆ında; yoksulluğa ve sosyal politikalara etkisi değerlendirilecektir.

1980'li yıllarda küreselleşme ile dünya hızlı bir dönüşüm sürecine girmiştir. Bu yıllarda özellikle liberal değerlerin egemenliği altında bir yandan piyasa ekonomisinin yaygınlaşması diğer yandan piyasaların bütünleşmesi ve küresel piyasaya dönüşmesi hedeflenmiştir. Küreselleşmenin süratle ulaşmak istediği bu hedefe, herhangi bir ülkenin veya ideolojinin karşı gelme olanağı o dönem gelişmemişti. Atılan adımlar küreselleşmeye karşı koymanın aksine, küreselleşmeyi ulusal amaçları ve ulusal şirketlerinin çıkarları doğrultusunda kullanmak yönünde olmuştur. Hatta küreselleşmenin kurallarını şirketlerin çıkarları doğrultusunda belirleyerek bu hedefi ikinci ve üçüncü dünya ülkelerine de dayatmışlardır (Ertuğrul, 2004). Küreselleşme süreci bu bakımdan dünyanın "alternatifsiz" yaşamak durumunda bırakıldığı bir dönüşüm olarak tanımlamaktadır (Dulupçu, 2001, s.16-17).

Keynesci kuram, büyük bunalımın olduğu 1930 yılları sonrası hâkim paradigmaya dönüşmüştür. Bu kuram, 1980'lere gelinceye kadar hakim paradigma olarak devamlılığını sağlamıştır. Bu yıllar arasında, devletler işsizliğe yönelik mücadelede ve ekonomik kalkınmada bu kuramı temele alarak etkin rolünü sürdürmüştür. Sonraki yıllarda ise liberal ekonomi ve liberal devlet 
paradigmasına yeniden dönüş yaşanmıştır. Keynesci paradigma giderek etkinliğini yitirmiş ve piyasada "bırakınız yapsınlar" dönemi egemenliğini arttırmıştır (Talas 1993: 9-10). Küreselleşmeyle ulus devletlerin ekonomideki rolünde değişikler meydana gelmiş ve bunun sonucunda çok uluslu şirketler ekonominin yeni öznesi haline gelmeye başlamıştır.

Küreselleşme sürecinde devletlerin piyasalar üstündeki hakimiyetinin küçülmesi gerekli görülmüştür. Bu anlayış sonucunda devlet kurumlarının düzenleyici, üretici ve paylaştırıcı işlevlerinin askıya alınması dönemine geçilmiştir. Bu da özellikle refah politikalarının sermaye tarafından yeniden değerlendirilmesine neden olmuştur (Thandika, 2004). Küreselleşme süreciyle yoksulluk, işsizlik gibi sosyal sorunların ciddi boyutlara ulaşması ve tüm teknolojik gelişmelere karşın bu durumun üstesinden gelinememesi sosyal politikaları mercek altına almayı gerekli kılmıştır.

Neoliberalizm kıskacında sosyal politikalara aktarılan kaynaklar 1980'lerden itibaren giderek azaltılmıştır. Edwards ve arkadaşları (1996) neoliberal politikaların etkin olduğu günümüzde, devletlerin sosyal amaçlarını açıça ifade ettiğini ancak vatandaşlarına kapitalizmin yarattı̆̆ olumsuz durumlardan daha fazla korumayı taahhüt edemediğini ifade etmektedir. Özetle, neoliberal küreselleşme ideolojisinin sosyal politikalara yansıması, sosyal politikaların dayanaklarının giderek zayıflaması ve bütçe sınırlılıkları üzerinden gerçekleşmiştir. Aynı zamanda bu sınırlamaların topluma göreli yoksulluk olarak yansıdığı da belirtilmektedir (Steger, 2004, s.65). Sosyal politikaların gelecekteki durumu üzerine yaptıkları çalışmada Meares ve Deroos (1997, s.376), "ülkenin ekonomisinin yeniden yapılanması sürecinde yoksullar ve zenginler arasındaki boşluğun daha da büyüyeceğini ve bu durumdan çocukların, kadınların ve azınlıkların daha çok etkileneceğini" ifade etmişlerdir.

Özetle, neoliberal küreselleşme sürecinin tarihsel ve ideolojik etkileri sosyal politikaların tanımlanması ve uygulanması konusunda yapısal değişikliklere neden olmuştur. Bu değişiklilerin başında piyasa için engel ve yük olarak görülen refah devleti ve refah devleti aracıllğıyla sosyal politikalar için yapılan harcamalar gelmektedir. Bu sebeple; sosyal harcamalara yönelik ana akım iktisat kuramının da yardımıyla eleştiriler gerçekleştirilmiş̧ir. (Thandika, 2004). Bu eleştiriler aynı zamanda neoliberal ekonomi politikalarının pekiştirilmesine ve tüm dünyada hız kazanmasına olanak tanımıştır. 


\section{Neoliberalizmin Hiz Kazanması}

Neoliberal küreselleşmeyle ortaya çıan özelleştirme, yerelleşme, sendikasızlaştırma, güvencesizleştirme gibi yapısal uyum politikalarının hız kazanması, refah devletinin etki alanının daralmasına neden olmuştur (Erdoğdu, 2004). Yaşanan bu gelişmeler ve refah devletinin giderek daralan etki alanı, yoksulluk sorunsalı ve sosyal politikalarda da dönüşüme sebep olmuştur.

Neoliberal küreselleşme, küresel düzeyde bütünleşmiş serbest bir piyasanın oluşumunu amaçlamaktadır. Bu amaç doğrultusunda neoliberal küreselleşme; ithalat ve ihracatı kısıtlamaya yönelik korumacı politikaların azaltılmasını, devlet tekellerinin kaldırılmasını ve bunların özelleştirilmesini, mal, hizmet ve sermayenin uluslararası dolaşımına engel oluşturacak her türlü kamusal düzenlemelerin kaldırılmasını, kısa dönemde sermaye hareketlerinin ve doğrudan yabancı yatırımlarının her türlü denetimden uzak tutulmasını, çalışma yaşamına yönelik düzenlemelerde kuralsızlaştırmanın sağlanmasını hedeflenmektedir (Kazgan, 2000, s.94). Neoliberal küreselleşme ile dünya üzerinde yaratılan serbest piyasa koşullarıyla rekabet de artık uluslararası düzeyde gerçekleşmektedir. Refah devletleri de dünyanın birçok yerinde piyasaya eklemlenerek, uluslararası rekabete dahil olmaya çalışmaktadır. Dolasıyla, küresel piyasaya uyum sağlamak adına devletlerin, sosyal politikalarda ciddi küçülmelere gitmesi yoksulluk sorunsalını derinleştirmektedir.

Neoliberal küreselleşme sayesinde sermayenin serbest dolaşımı, ülkeler arası eşitsiz gelişime ve sömürüye neden olmaktadır (Çağlı, 2006). Batı toplumlarında işçi direnişlerinin kazanımları, sosyal politikaların iyileştirilmesine ve emek piyasalarının dönüşümüne katkı sunmuştur. Batı merkezli işçi sınıfının kazanımları sayesinde, diğer toplumlara oranla oradaki işçiler, belirli sosyal hak ve güvencelere sahip olmuştur. Bu durum, batıdaki emek temelli ağır sömürü şartlarının nispeten iyileştirilmesine katkı sunmuştur. Dolayısıyla artık sermaye batı toplumlarında ucuz emek üzerinden yüksek kar getirisine sahip olmamakta, bu sebeple de rahatlıkla ucuz iş gücünü bulabileceği üçüncü dünya ülkelerinde veya az gelişmiş ülkelerde üretimini gerçekleştirmektedir (Milberg, 2004; Palley, 2008). Ayrıca, sermayenin Batı merkezli kalması için çeşitli önlemler de alınmıştır. Öncelikle Ar-Ge çalışmalarının merkezinin batı odaklı olması ve çeşitli anlaşmalarla sermayenin kayması engellenmeye çalışılmaktadır. Az gelişmiş ülkelerde devletlerin sermayeyi çekmek için uyguladıkları politikalar bu durumu pekiştirmekte dolayısıyla bu 
ülkelerde sömürüyü ve yoksulluğu her geçen gün arttırmaktadır. Bu sürecin genel olarak, sömürüye karşı birlikte direnişin parçalanmasına ve ülkeler arasındaki eşitsizliğin her geçen gün artmasına neden olmaktadır.

Keynesyen refah devleti, kitlesel üretimi, iş bölümünü ve tam süreli istihdamı ön gören Fordist üretim sistemini temele almıştır. Böylelikle sosyal sigortaların finansmanını kolaylaştırmış ve toplumun geniş bir kesiminin sosyal güvenlik kapsamına alınmasını sağlamıştır. Neoliberal küreselleşme süreciyle birlikte gelişen "esnek çalışma" anlayışıyla sistemin temelini oluşturan "düzenli ve sürekli iş" kavramı giderek ortadan kalkmaya başlamıştır (Güzel, 1999, s.34). İşçilerin sabit bir işe, düzenli bir gelire sahip olduğu ve emeklilik planlarının korunduğu refah devletine karşın, neoliberalizmin güvencesiz, sigortasız ve esnek çalışma politikaları işçilerin yaşamında köklü değişimlere neden olmuştur (Burrows, 2013). Bu ani değişime ayak uyduramayan toplumlar ve bireyler akışkan ve sürekli değişen işlerde çalışmakta zorluk çekmişlerdir. Serbest piyasa şartları altında tutunamayan kesimler; düzenli ve sürekli işlere şartları kötü bile olsa dört elle sarılmaya başlamıştır (Çakır, 2007). Çalışma yaşamında esnek istihdam politikalarının uygulanması, sermaye açısından avantajlıyken, bireyler açısından işsizlik ve yoksulluk riskini arttırmıştır. Bu durum kuralsız, güvencesiz, sendikasız ve düşük ücretler ile çalıştırılmanın yaygınlaştığı ve işçi sınıfının büyük bir kısmını yoksulluğa iten bir süreç yaratmıştır (Erdoğdu, 2004). Çalışmak yoksulluğun çaresi olmaktan giderek uzaklaşmış; düzeni olmayan ve güvence aranmayan işler çalışan yoksulların kaynağı haline gelmiştir. Sonuç olarak, neoliberal küreselleşme ile çalışan yoksulların sayısı her geçen gün artmıştır.

Neoliberal küreselleşme süreciyle artan sosyal eşitsizlik ve adaletsizlik, sosyal politikanın başlangıçtaki işlev ve amacının güncelleşmesini zorunlu kılmıştır (Gülmez, 2000, s.2). Böylelikle de küresel ekonominin sebep olduğu sosyal sorunlarla mücadele edebilmek için küresel boyutta sosyal politika uygulamaları zorunlu hale gelmiştir. Günümüzde sosyal politikaların başlangıçtaki kapsamı genişleyerek sadece işçi odaklı olmayıp, kadın, çocuk, engelli, yaşlı vs. gibi toplumda dezavantajlı grupları da içine alacak şekilde politikalar geliştirilmiştir (Çağl1, 2006). Bu politikaların yapısına ve işleyiş̧lerine baktığımızda; hala süregelen eşitsizliklerin bulunduğunu görmekteyiz. Öncelikle sosyal politikalar sıklıkla egemenin anlayışına paralel olarak adil olmayan bir şekilde dağıtıma girmektedir. Ayrıca devletler, sosyal politikalarla 
yoksullar üzerinden siyasi ve ekonomik rant sağlamanın yanı sıra onları kontrol altında tutma gücünü de kendinde toplamaktadır.

Sonuç olarak; neoliberal paradigmanın refah devletine, yaratıcısı oldukları yoksulları hedef alarak getirdiği eleştiriler şunlardır: Refah devleti, liberallere göre bir bakıma yoksulluğun da yaratıcısı olmakta ve yoksulluğun yeniden üretilmesine katkı sağlamaktadır. Liberal eleştiri, devletlerin yoksullara sağladıkları sağlık, eğitim, barınma gibi sosyal hizmetlerin yetersiz ve kalitesiz oldukları için buraya ayrılan kaynakların da bir anlamda hem boşa gitmekte olduğunu hem de bunları sağlamak için toplanan yüksek vergilerin özel yatırımları azaltacağına, dolayısıyla uzun vadede işsizlik ve yoksullukla karşı karşıya kalınacağını belirtmektedir. Sosyal yardım politikalarının 'insanların çalışmasını önlediği' ve 'bağımlılık kültürü' oluşturduğunu ve refah devletinin insanlarda tembellik yarattığını ileri sürerek, yoksulluğu tetiklediğini ifade etmektedirler (Handler, 2003, s.230). Bu anlamda liberal anlayış, refah devletini ülkelerin gelişimi önünde bir engel olarak görmektedir.

\section{Tartışma ve Yorum}

Neoliberal küreselleşmenin güç kazanmasıyla, yoksullukla boğuşan dünyada kaynakların adil kullanılmadığının, aynı şekilde yatırımların da adil yapılmadığının, özellikle sosyal politikaların sermaye tarafından gelişmenin önünde yük olarak görüldügüne tanık olmaktayız. Çok uluslu şirketlerin başını çektiği neoliberal küreselleşme süreciyle, ülkelerin özellikle sosyal güvenlik sistemlerinin ve refah devleti uygulamalarının maliyetleri yükseltici etkileri sorgulanmaya başlanmıştır. Bu sorgulamalar da nihayetinde sermayenin lehine işleyerek, sosyal politikaların alanının daralmasına ve yoksulların üzerindeki baskının ve sömürünün artmasına neden olmuştur.

Neoliberal küresel ekonominin hâkim olduğu günümüz dünyasında, kapitalist paradigmanın krizlerinin sonucuna alternatif olarak beliren refah devleti, yine neoliberal küresel politikaların baskısı neticesinde, uygulamalarının giderek azaltıldığı ya da uygulanmaktan giderek vazgeçildiği bir süreci yaratmıştır. Bu göstergeler dünyadaki yoksulluk sorunsalının çözülmesine karşı adımlar olmaktan ziyade sermayenin kazancını arttırmaya yönelik olmuştur. Ayrıca kapitalist paradigma, sosyal politikalar üzerinden içinde bulunduğu krizleri aştığı gibi onu tehdit eden sosyalist rejimlere karşı 
da görece zafer kazanmış, işçi ve yoksulların sistem karşıtı direnişlerini parçalama ve kırmanın yolunu bulmuştur. Özellikle Avrupa'da sosyal refah devletleri, ortalama otuz-kırk yıllık bir süre boyunca "altın çağını" yaşamış olsa da, neoliberal politikaların büyük oranda dünyaya hakim olmasıyla, sosyal refah devleti anlayışı bir ara dönem olarak bırakılmaya çalışılmıştır.

Neoliberal küreselleşme döneminde sosyal politikalarda, işçi ve yoksul kesimin direnişleri neticesinde belirli oranda iyileştirmeler yapılmış olsa da, işçi ve yoksulların haklarının sınırları sistem tarafından çizilmiş ve beraberinde işçi sınıfının ve yoksulluğun ayrışmasına ve pasif hale gelmesine neden olmuştur. Artık bu gruplarda protesto ve hak talepleri belirli sınırlar içinde gerçekleşmekte ve bu protesto ve hak arayışları egemenin çizdiği sınırlara tabi tutulmaktadır. Dolayısıyla, neoliberal küreselleşme ile sosyal politikalar araçsallaştırılarak ve kapitalizm ve sömürgeciliğinin gerçek yüzünü perdeleyerek yoksulluğun örtükleşmesine olanak sağlamaktadır.

Sonuç olarak, neoliberal küreselleşme ile sermayenin küresel düzeyde bütünleşme hedefi, beraberinde sömürünün ve yoksulluğun küresel boyutlarını da açığa çıkarmıştır. Günümüzde artık yoksulluk sorunsalını sadece yerel dinamiklerle açıklamak mümkün değildir. Yoksulluğun küresel boyutlara ulaşmasıyla ile birlikte yerelin yoksulluğu diğer ülkeleri de rahatlıkla etkileyebilmektedir. Örneğin; günümüzde gelişmiş Batı toplumlarının en büyük kâbusu yoksul göçmenler olmaktadır. Yoksul göçmenlere yönelik çözümler de çoğunlukla yoksulları dışarıda tutacak şekilde tasarlanan sosyal politikalarla sağlanmaya çalışılmaktadır. Bu durum yoksulluğun ve sosyal politikaların küresel görünümü açısından önemli birçok noktayı işaret etmektedir. Umulmaktadır ki, neoliberal kapitalist küreselleşme nasıl sömürüyü ve yoksulluğu küresel hale getirdiyse, bütün baskı ve stratejilere rağmen yoksulluğa karşı direniş de küresel boyutlara ulaşacaktır. 


\section{EXTENDED ABSTRACT}

\section{A Discussion on Neoliberal Globalization, Changing Social Policies and the Problem of Poverty

\author{
* \\ Orhan Orhun- Osman Şimşek \\ Batman University-Adnan Menderes University
}

The problem of poverty is one of the most important problems of today's postmodern world. The poverty problem, which has a very wide historical process, reached one of its climaxes with the Industrial Revolution, which caused radical changes in human history. With the capitalist production relations in the Industrial Revolution, the two extreme classes of capital and labor in society occupied a central place in the stage of history. In the Industrial Revolution that progressed on the basis of the capitalist paradigm, the bourgeois class, which is a minority in the society, got richer day by day, while the workers, who constitute the majority of the society, drifted towards impoverishment. With this polarization, while poverty became massive on the one hand, on the other hand, wealth concentrated in the hands of a handful of minorities. Changes in industrial technology have forced the majority of the rural population to migrate to cities as workers. The labor force, which was detached from natural habitats and dispossessed, had to sell their labor in urban factories to factory owners for a fee. This relationship between factory owners and workers is basically based on the heavy exploitation of labor. Workers were either not compensated for their labor or were forced to work under low wages and poor conditions. One of the important developments of this period is the rapid inclusion of machines in the production process. Thus, muscle power has been replaced by machines day by day, so the need for human labor has decreased day by day. In this case, it has caused those who have difficulties in making a living with their labor, the army of the unemployed backed up to the periphery of the cities, the agricultural laborers, the propertyless peasants from the countryside, in short, the excluded masses who have to take less than what they produce and who are not allowed to use their labor, and who are not even able to become laborers. Finally, it 
should not be forgotten that the relationship between the welfare state and poverty is bidirectional; It also causes them to reproduce each other constantly.

In this study, the transformation and appearance of the poverty problem and social policies through the historical process in the projection of neoliberal globalization have been analyzed. In this context, the discussion has primarily dealt with the industrial revolution, in which the poverty problem deepened, and the controversial intellection of the welfare state in this period. Then, in the grip of neoliberal globalization that dominates the stage of history; new poverty and social policies have constituted the focus of the discussion. Moreover, in today's world dominated by the neoliberal global economy, the welfare state, which emerged as an alternative to the results of the crises of the capitalist paradigm, has created a process in which its practices are gradually reduced or abandoned gradually, as a result of the pressure of neoliberal global policies.

Although the historical background of the phenomenon of poverty and social policy has a long history, the study has been analysed on the basis of the industrial revolution and subsequent periods, where its visibility has become clear. With the industrial revolution, the poverty problem and social policies have become more evident than in any other period of the history. Changes in poverty and social policy perception have also been with globalization and rising neoliberal policies after the industrial revolution. Finally, the rise of the consumer society with neoliberal globalization has led to new discussions over the social policy and the poor. This study aims to discuss the poverty problem from multiple perspectives within the framework of these basic dynamics. From this perspective, this study examines the fundamental changes in the Industrial Revolution period and the reflections of these changes on the current global structure with a critical perspective using the literature review technique. This study, which discusses how unemployment and poverty have deepened day by day within the framework of these radical changes, questions the emergence of the welfare state and the social policies it brings with it through economic and social life. In this study, in which the question and criticism of the implementation of Keynesian policies related to the welfare state and social policies is made later, the poverty problem in today's economic and social structure conceptualized as neoliberal globalization is 
examined. As a result, neoliberal globalization and the aim of global integration of capital have also revealed the global dimensions of exploitation and poverty. Today, it is no longer possible to explain the problem of poverty only with local dynamics. With poverty reaching global dimensions, local poverty can easily affect other countries.

\section{Kaynakça / References}

Acar, M. (2007). Keynesyen iktisat ve refah devletinin sonu, dünü ve bugünüyle sosyal demokrasi. Demokrasi Platformu Dergisi, 3(9), 38-57.

Aydoğanoğlu, E. (2010). İş̧̧i simfit tarihi. İstanbul: Tarem Yayınları.

Bahçe, S. ve Köse, A. (2018). Kapitalizmin yoksulluğu: Vatandaş ya da toplumsal sınıf olarak yoksullar. İçinde: D Kutlu (der), Sosyal yardım alanlar emek, geçim, siyaset ve toplumsal cinsiyet. İstanbul: İletişim Yayınları, 41-57.

Başkaya, F. (2000). Küreselleşmenin karanlık bilançosu. Ankara: Özgür Üniversite Kitaplığı. No: 31.

Bauman, Z. (1999). Çalışma tüketicilik ve yeni yoksullar. Ümit Öktem (Çev.). İstanbul: Sarmal Yayinevi.

Bauman, Z. (2003). Yasa koyucular ile yorumcular. (2.bask1). Kemal Atakay (Çev.). İstanbul: Metis Yayınları.

Burrows, S. (2013). Precarious Work, neo-liberalism and young people's experiences of employment in the illawarra region. The Economic and Labour Relations Review, 24(3), 380-396.

Carly, O. (1996). Modemity and the State: East, West. Cambridge: Polity Press.

Clasen, J. (2003). Towards a New Welfare State Or Reverting To Type? Some Major Trends In British Social Policy Since Early 1980s. The European Legacy, 8(5), 560-583.

Çağll, E. (2006). Küreselleşme, eşitsiz ve bileşik gelişme. İstanbul: Tarih Bilinci Yayınları. Çakır, Ö. (2007). İşini kaybetme kaygısı: İş güvencesizliği. Çalışma ve Toplum Dergisi, 1, 117-140.

Dulupçu, M. A. (2001). Küresel rekabet gücü: Türkiye üzerine bir değerlendirme. (1. Basım). Ankara: Nobel Yayın Dağıtım.

Durdu, Z. (2009). Modern devletin dönüşümünde bir ara dönem: Sosyal refah devleti. Muğla Üniversitesi Sosyal Bilimler Enstitüsü Dergisi, 22, 37-50.

Edwards R. L., Cooke P. W. and Reid, P. N. (1996) Social work management in an era of diminishing federal responsibility. Social Work, 41(5), 468-479. 
Erdoğdu, S. (2004). Sosyal politikada 'Avrupalı' bir kavram: Sosyal dışlanma. Çalışma Ortami Dergisi, 75, 12-14.

Ertuğrul, C. (2004). Tarımda küreselleşme - Uruguay görüşmeleri ve sonrası. Ankara: Odak Yayınevi.

Gülmez, M. (2000). Uluslararası sosyal politika. Ankara: TODAiE yayınları.

Güven, S. (1995). Sosyal politikann temelleri. Bursa: Ezgi Kitabevi.

Güzel, A. (1999). Sosyal güvenliğin çağdaş dinamikleri. Toprak İşveren Dergisi, 50, 650.

Handler, J. F. (2003). Social citizenship and workfare in the US and Western Europe: From status to contract. Journal of European Social Policy, 13(3), 229-243.

Harvey, D. (2007). A brief history of Neoliberalism. Oxford: Oxford University Press.

Himmelfarb, G. (1984) The ldeas of poverty: England in the Erly Industrial Age. Londra: Faber \& Faber.

İkin, A. (1973). Endüstrileşme. Ak İktisat Ansiklopedisi, Cilt II, İstanbul: Ak Yayınları.

Kazgan, G. (2000). Küreselleşme ve ulus devlet-yeni ekonomik düzen. İstanbul: İstanbul Bilgi Üniversitesi Yayınları.

Koray, M. (2008). Sosyal politika. Ankara: İmge Kitapevi.

Marcuse, H. (1968). Tek boyutlu insan. S. Çağan (Çev.), İstanbul: May Yayınları.

Marx, K. (2011). Kapital ekonomi politiğin eleştirisi 1. cilt sermayenin üretim süreci. Mehmet Selik ve Nail Satligan (Çev.), İstanbul: Yordam Kitap.

Meares P. A. and Deroos Y. (1997). The future of social work profession. Social Work in the 21st Century. Ed: Michael Reisch ve Eileen Gambrill, 376-387.

Milberg, W. (2004). The changing structure of trade linked to global production systems: What are the policy implications?. International Labour Review, 143, 4590.

Özbudun, E. (1995). Türk Anayasa hukuku. Ankara: Yetkin Hukuk Yayınları.

Özdemir, S. (2007). Küreselleşme sürecinde refah devleti. İstanbul: ITTO Yayınları.

Palley, T. (2008). The economics of outsourcing: How should policy respond? Review Of Social Economy, 66(3), 279-295.

Rosanvallon, P. (2004), Refah devletinin krizi. Ankara: Dost Kitabevi.

Sallan Gül, S. (2004). Sosyal devlet bitti, yaşasm piyasa!. İstanbul: Etik Yayınları.

Sezen, S. (1997). Devletçilikten özelleştirmeye türkiye'de planlama. Ankara: TODAï Yayınları.

Steger, M. B. (2004). Küreselleşme. Abdullah Ersoy (Çev.), Ankara: Dost Yayınları.

Şenkal, A. (2005). Küreselleşme Çă̆gnda Sosyal Politika, İstanbul: Alfa Yayınları.

Talas, C. (1993). Liberalciliğin geri dönüşü ve sonrası. Amme İdaresi Dergisi, 26(3), Ankara. 
Neoliberal Küreselleşme, Değişen Sosyal Politikalar ve Yoksulluk Sorunsalı Üzerine Bir Tartışma

Thandika, M. (2004). Social policy in a development context. New York: Palgrave Macmillan.

Yilmaz, E. (2005). Hukuk sözlü̈̆̈̈̈. Ankara: Yetkin Yayınları.

Zastrow, C. (2015). Sosyal hizmete giriş. D. B. Çiftçi (Çev.) Ankara: Nika Yayınları.

\section{Kaynakça Bilgisi / Citation Information}

Orhun, O. ve Şimşek, O. (2021). Neoliberal küreselleşme, değişen sosyal politikalar ve yoksulluk sorunsalı üzerine bir tartışma. OPUSUluslararası Toplum Araştırmaları Dergisi, 18(41), 3755-3777. DOI: 10.26466/opus.934568. 